\title{
Web Unevenness Due to Thermal Deformation in the Roll-to-Roll Manufacturing Process
}

\author{
Minho Jo ${ }^{1}$, Jongsu Lee ${ }^{2}$, Seongyong Kim ${ }^{1}$, Gyoujin Cho ${ }^{3}$, Taik-Min Lee ${ }^{4}$ \\ and Changwoo Lee $5, * \mathbb{D}$ \\ 1 Department of Mechanical Design and Production Engineering, Konkuk University, 120 Neungdong-ro, \\ Gwangjin-gu, Seoul 05030, Korea; als8080@konkuk.ac.kr (M.J.); arsen6788@konkuk.ac.kr (S.K.) \\ 2 Department of Printed Electronics Engineering, Sunchon National University, 225 Jungang-ro, \\ Suncheon 57922, Korea; jslee0505@scnu.ac.kr \\ 3 Institute of Quantum Biophysics, Sungkyukwan University, 2066 Seobu-ro, Jangan-gu, Suwon 16419, Korea; \\ gcho1004@skku.edu \\ 4 Korea Institute of Machinery and Materials(KIMM), Intelligence and Precision Machinery Research Division, \\ 156 Gajeongbuk-ro, Yuseong-gu, Daejeon 34103, Korea; taikmin@kimm.re.kr \\ 5 Department of Mechanical Engineering, Konkuk University, 120 Neungdong-ro, Gwangjin-gu, \\ Seoul 05030, Korea \\ * Correspondence: leewoo1220@konkuk.ac.kr; Tel.:+82-2-450-3570; Fax: +82-2-454-0428
}

Received: 17 November 2020; Accepted: 30 November 2020; Published: 2 December 2020

\begin{abstract}
In roll-to-roll (R2R) processing, web uniformity is a crucial factor that can guarantee high coating quality. To understand web defects due to thermal deformation, we analyzed the effect of web unevenness on the coating quality of an yttria-stabilized zirconia (YSZ) layer, a brittle electrolyte of solid oxide fuel cells (SOFCs). We used finite-element analysis to study thermal and mechanical deformations at different drying temperature levels. A YSZ layer was also coated using R2R slot-die coating to observe the effect of web unevenness on coating quality. Web unevenness was generated by thermal deformation due to conduction and convection heat from the dryer. Because of varying web unevenness with time, the YSZ layer developed cracks. At higher drying temperatures, more coating defects with larger widths were generated. Results indicated that web unevenness at the coating section led to coating defects that could damage the SOFCs and decrease yield in the R2R process. Coating defects generated by web unevenness caused by convection and conduction heat should be considered in the high-volume production of brittle electrolytes using the R2R process.
\end{abstract}

Keywords: coating defect; electrolyte layer; temperature; thermal deformation; roll-to-roll slot-die coating systems; wrinkle

\section{Introduction}

The roll-to-roll manufacturing (R2R) process is ecofriendly and low-cost, and has the advantage of mass production, which makes it attractive in manufacturing flexible electronic devices such as thin film transistors and solid oxide fuel cells (SOFCs) [1-5]. Recently, a brittle electrolyte, which is a separator used in SOFCs to transmit oxygen ions, was coated using this R2R process [6]. Slot-die coating is one of the best methods for coating a large-area electrolyte using this process. In slot-die coating, ink is supplied at a constant flow rate to the reservoir of the slot-die coater, discharged through the coater lip while forming a coating bead, and then deposited on the web. The coating quality of the liquid varies according to the distance between coater lip and web (coating gap), ink viscosity, ink surface tension, and substrate surface energy [7]. Accordingly, many research groups studied the effects of ink properties and coating parameters on coating quality [8,9]. One of the most important parameters in the $\mathrm{R} 2 \mathrm{R}$ process is the uniformity of the web obtained in the transverse direction. As 
such, the material of the web used to coat the electrolyte should be a thin, flexible, nonbreakable plastic film such as polyethylene terephthalate (PET) or polyimide (PI) [10-12]. Moreover, the web can be easily deformed by external forces due to the roll eccentricity and temperature fluctuations of the heater in the dryer during the movement of the web, which could deteriorate coating quality. Therefore, numerous studies on the behavior of the web according to external forces were conducted.

Ebler et al. [9] developed a mathematical model to express the behavior of tension applied to the web in the R2R process, and controlled web-tension disturbances using a load cell and passive dancer. Sakamoto et al. [13] proposed a web-tension control method based on a proportional-integral (PI) controller and analyzed the tension behavior according to different velocity variations of driven rollers using the developed model. Lynch et al. [14] proposed an efficient web-tension estimation method using a nonlinear model-based observer, followed by experimental verifications. Shin et al. [15] analyzed web-tension behavior in the transverse direction. Lee et al. [16] postulated that the surface roughness of the substrate depends on web-tension disturbances in the R2R process, which affect coating and printing qualities. Lee et al. [17] analyzed the effects of temperature disturbance in the dryer on thermal characteristics of the web followed by experimental verifications. Lu et al. [18] studied web behavior according to heat conducted by the heating rollers in the R2R process.

As mentioned above, previous studies mainly considered tension fluctuation in the web due to the velocity variations of driven rollers and temperature disturbances in the dryer in the R2R process. However, few studies were conducted on web defects due to thermal deformation of the dryer inlet [7]. Thermal deformations of the web could generate sine-wave-shaped deformation of the web in the transverse direction (web unevenness). If such web unevenness occurs in the coating section, the coating bead may become unstable, and the thickness of the coating layer may become nonuniform even though the desired coating parameters are set. Moreover, a crack could be generated by the bending of the coating layer due to web unevenness if brittle material is coated on the uneven web. These coating defects can negatively affect the performance of devices constructed on the coated layer $[19,20]$. Therefore, it is essential to study defects at the inlet of the dryer during the coating of a brittle material to obtain a high-quality electrolyte layer in the R2R process.

In this study, we analyzed the effect of thermal deformation in the tensioned web and web unevenness near the inlet of the dryer on the coating quality of a brittle electrolytic layer. First, the behavior of the tensioned web was analyzed according to drying temperature using finite-element analysis (FEA). A finite-element model (FEM) was designed considering the boundary conditions and external forces applied to the web near the inlet of the dryer. Simulation results showed that thermal deformation of the web led to web unevenness, and amplitude increased with a higher drying temperature. Lastly, yttria-stabilized zirconia (YSZ), an electrolyte of SOFCs, was coated by an R2R slot-die coating process at various drying temperature levels to clearly observe the effects of web unevenness on the coating quality of the YSZ layer and the performance of the SOFCs that were fabricated using this layer.

\section{Finite-Element Analysis: Thermal-Structural Coupling Analysis}

A thermal-structural coupling analysis was carried out using FEA. Considering the boundary conditions at the inlet of the dryer and external forces applied to the web, an FEM of the web near the inlet of the dryer was designed to understand web deformation due to convection and conduction heat from the dryer.

\subsection{Finite-Element Modeling}

A PET film (CD-901, KOLON Inc., Korea) was used in this study. Table 1 presents the mechanical and thermal properties of the web; boundary conditions defined for the model are shown in Table 2. 
Table 1. Mechanical and thermal properties of polyethylene terephthalate (PET) flexible substrate.

\begin{tabular}{ccc}
\hline Property & Unit & Value \\
\hline Density & $\mathrm{kg} / \mathrm{m}^{3}$ & 1390 \\
Poisson's ratio & - & 0.33 \\
Young's modulus & $\mathrm{MPa}$ & 4800 \\
Specific heat & $\mathrm{J} / \mathrm{kg} \mathrm{K}^{-1}$ & 1172 \\
Thermal-expansion coefficient & $\mathrm{K}^{-1}$ & $1.7 \times 10^{-5}$ \\
\hline
\end{tabular}

Table 2. Boundary conditions in thermal-structural coupling analysis.

\begin{tabular}{cc}
\hline Physics & Boundary Condition \\
\hline Mechanical & Fixed support \\
Mechanical & Tension \\
Thermal & Drying temperature \\
Thermal & Drying area expansion \\
\hline
\end{tabular}

Figure 1a indicates the schematics of the web transporting and drying sections in the R2R process. Figure $1 b, c$ present enlarged views of the section and tension distribution, respectively, at the inlet of the dryer indicated by the black-dotted box in Figure 1a. In Figure 1b, x, y, and z directions were taken as the web-moving, transverse, and web-thickness directions, respectively. In Figure 1a, it was inferred that web temperature steadily increased and converged to the drying temperature due to conduction and convection heat from the dryer as the web was close to the inlet of the dryer. The temperature distribution of the web in the FEM was set considering the temperature distribution at this position. Considering the tension distribution shown in Figure 1c, boundary conditions at both edges were defined, and set tension was applied to both sides of the web [21]. The drying temperature range was set from 30 to $120^{\circ} \mathrm{C}$ considering the temperature range of the actual dryer in the R2R process. Solid 226 was used as the element in the FEM to carry out multiphysics coupling analysis using a commercial finite-element analysis program (ANSYS Fluent, ANSYS Inc., Canonsburg, PA, USA). Equation (1) represents the governing equation to calculate the net thermal deformation in Solid 226 on the basis of thermal-structural coupling analysis.

$$
\{\varepsilon\}=[D]^{-1}\{\sigma\}+\{\alpha\} \Delta T
$$

where $\{\varepsilon\}$ is the total strain vector, $[D]$ is the elastic stiffness matrix, $\{\sigma\}$ is the vector of coefficients of thermal expansion, and $\Delta T$ is the temperature variation. Although there was a web where permanent deformation occurred after the thermal cycle, such as slit-extruded PET foils, permanent deformation after the thermal cycle was ignored because this study considered the correlation between thermal deformation inside and outside the dryer, and coating performance. 
(a)

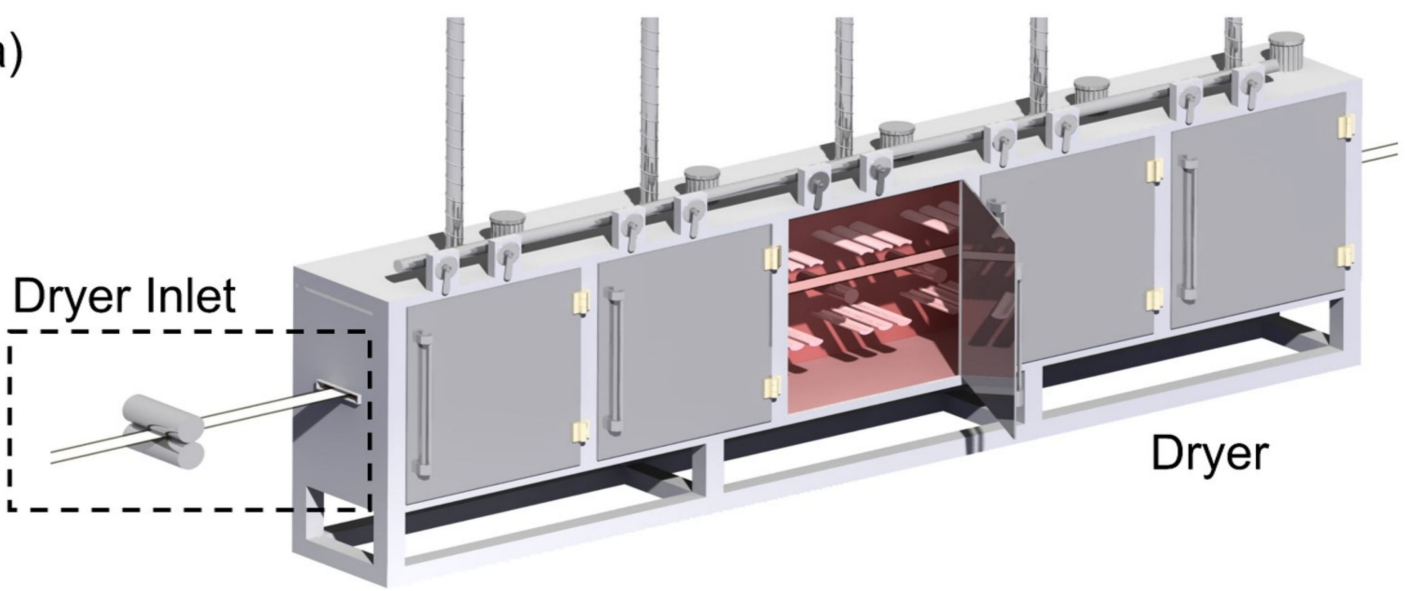

(b)

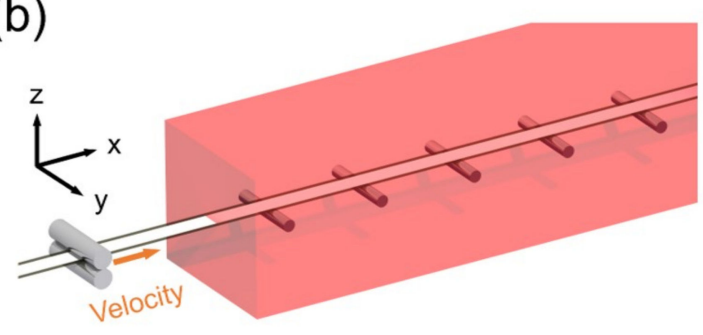

(c)

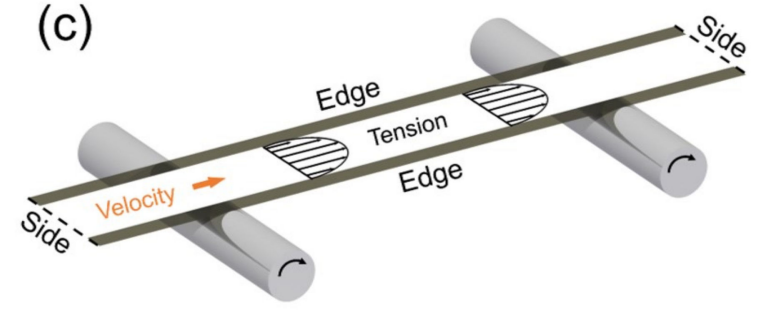

Figure 1. Schematic of flexible substrate in roll-to-roll (R2R) process. (a) Dryer; (b) detailed view of dryer inlet; (c) tension distribution on flexible substrate.

\subsection{Simulation Result}

Figure 2 presents the distribution of deformation (unit: $\mathrm{mm}$ ) in the tensioned web along the $\mathrm{y}$ and $\mathrm{z}$ directions, expressed as contour plots. To plot Figure $2 \mathrm{a}-\mathrm{d}$, web speed and tension of 1 $\mathrm{m} / \mathrm{min}$ and $1 \mathrm{kgf}$ were used, respectively. Drying-temperature levels were set to $30,60,90$, and 120 ${ }^{\circ} \mathrm{C}$. The length of the web model, that is, the distance between the slot-die coater and the inlet of the dryer, was $0.5 \mathrm{~m}$. Deformations were magnified 20 times to clearly observe their distributions in the tensioned web according to drying temperature. The legend at the right of each contour plot shows the web deformation with respect to the color of the contour plot. The white dotted line in all figures represents the inlet of the dryer. Figure 2a shows that many fewer deformations in the web occurred at the drying temperature of $30^{\circ} \mathrm{C}$ compared to those at $60^{\circ} \mathrm{C}$. The web was compressed by tensile stress in the transverse direction before the dryer inlet; however, the web expanded due to thermal expansion after passing through the dryer inlet. Thermal deformation in the $\mathrm{z}$ direction increased more rapidly than that in the y direction as drying temperature increased. In particular, one can clearly see sine-wave-shaped web unevenness after the inlet of the dryer at the $60^{\circ} \mathrm{C}$ drying temperature, as shown in Figure $2 \mathrm{a}-\mathrm{d}$. Table 3 shows the maximal deformation in the $\mathrm{y}$ and $\mathrm{z}$ directions according to drying temperature. Results show that drying temperature dominantly affected web deformation in the $\mathrm{z}$ direction compared to in the y direction. Web unevenness was generated by the thermal deformation caused by conduction and convection heat from the dryer. 
(a)
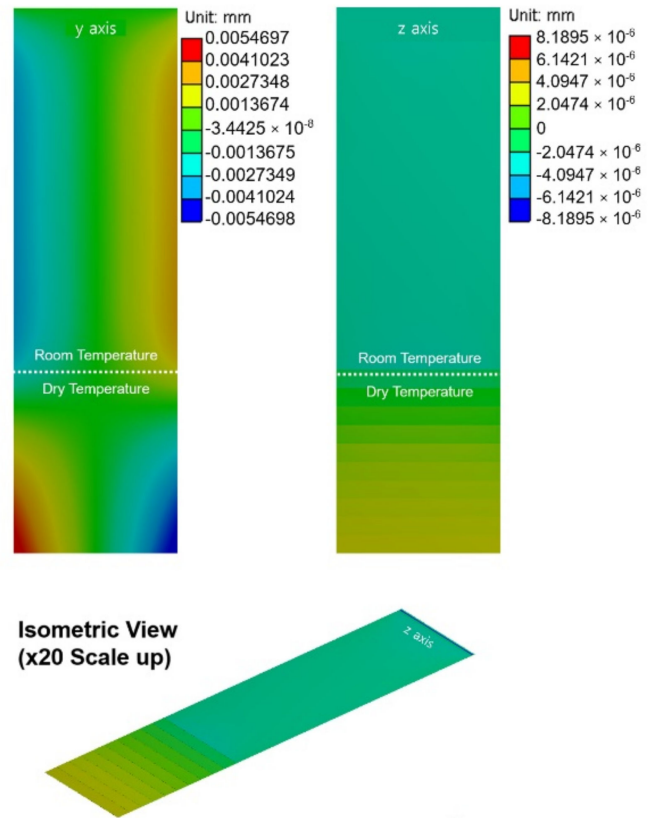

(c)
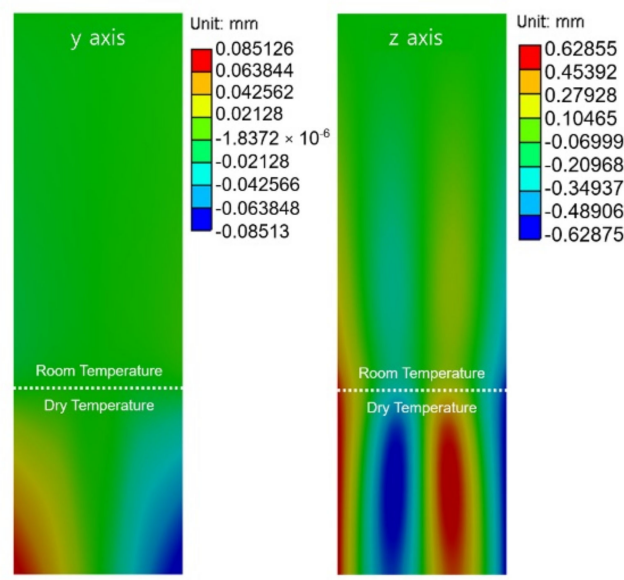

Isometric View (x20 Scale up)

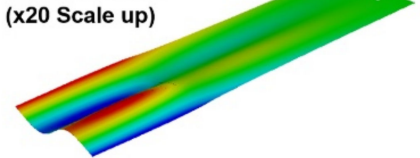

(b)
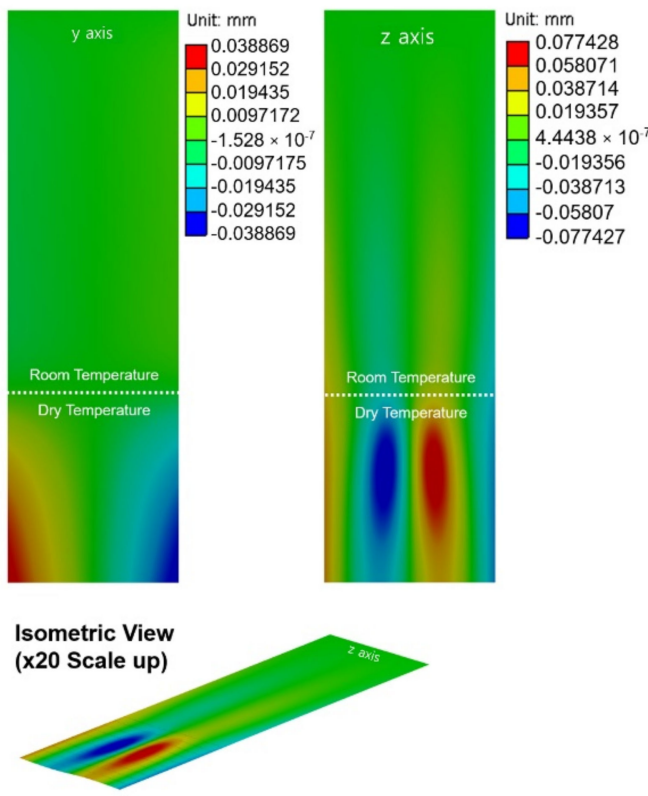

(d)
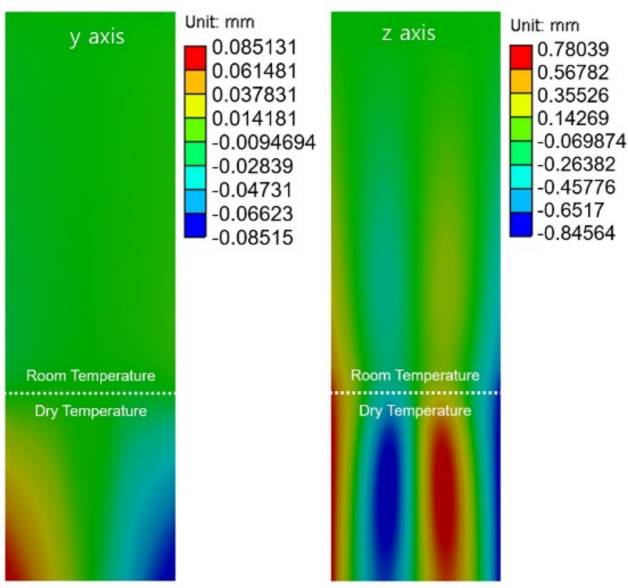

Isometric View (x20 Scale up)

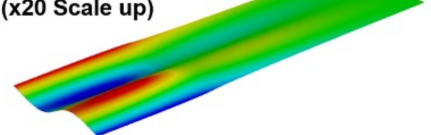

Figure 2. $\mathrm{Y}$ and $\mathrm{Z}$ axis deformation behaviors of flexible substrate at: (a) $30^{\circ} \mathrm{C}$, (b) $60{ }^{\circ} \mathrm{C},(\mathbf{c}) 90{ }^{\circ} \mathrm{C}$, and (d) $120^{\circ} \mathrm{C}$.

Table 3. Mechanical and thermal deformations of PET flexible substrate.

\begin{tabular}{ccc}
\hline Temperature $\left({ }^{\circ} \mathbf{C}\right)$ & Y Deformation $\left(\times \mathbf{1 0}^{-\mathbf{3}} ; \mathbf{m m}\right)$ & Z Deformation $\left(\times \mathbf{1 0}^{-\mathbf{3}} ; \mathbf{m m}\right)$ \\
\hline 30 & 5.4697 & 0.008 \\
60 & 38.869 & 77.428 \\
90 & 85.126 & 628.46 \\
120 & 85.299 & 780.39 \\
\hline
\end{tabular}

Figure 3 indicates the deformation of the web in the $y$ and $z$ directions according to drying temperature. The $x$ and $y$ axes of the plots indicate drying temperature $\left({ }^{\circ} \mathrm{C}\right)$ and web deformation $(\mathrm{mm})$, respectively. Deformation in the y direction increased and remained constant after $90{ }^{\circ} \mathrm{C}$. However, web deformation in the $\mathrm{z}$ direction steadily rose with increasing drying temperature. In particular, 
this deformation rapidly increased in the drying region of $60-90{ }^{\circ} \mathrm{C}$. Given that thermal deformation generated web unevenness, severe web unevenness could occur above a drying temperature of $60^{\circ} \mathrm{C}$. Web unevenness spread to the coating section, which generated coating defects due to the unstable coating bead and nonuniform web surface.

(a)

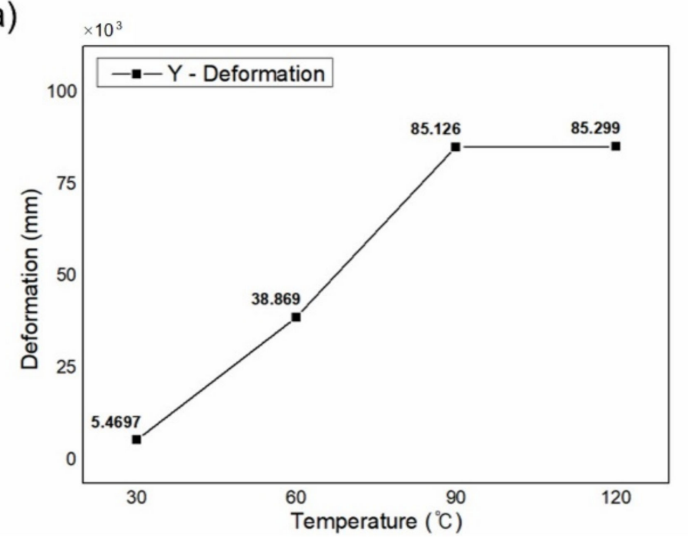

(b)

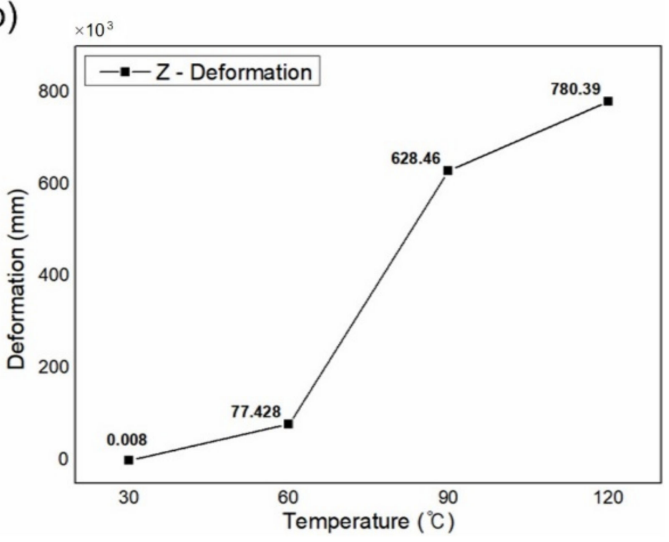

Figure 3. Deformation at temperature domain in (a) y and (b) z directions.

Figure $4 \mathrm{a}, \mathrm{b}$ show the web moving distance according to web moving time in the dryer, and the distribution of the consequent web unevenness. Web speed, tension, and drying temperature were 1 $\mathrm{m} / \mathrm{min}, 1 \mathrm{kgf}$, and $120^{\circ} \mathrm{C}$, respectively. Web unevenness was generated $3.05 \mathrm{~s}$ after the web entered the dryer. The amplitudes and positions of the peaks and valleys of web unevenness changed with respect to web moving time. Results suggested that the dried brittle layer on which the coating defect had occurred was prone to cracking by bending due to the change in web unevenness according to web moving time.

(a)

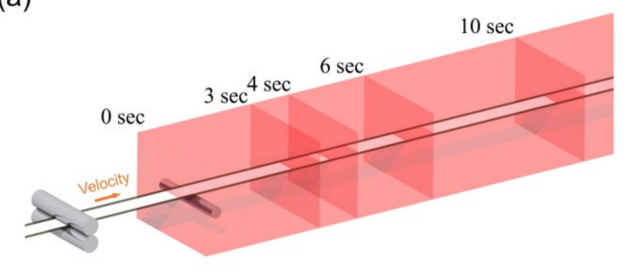

(b)

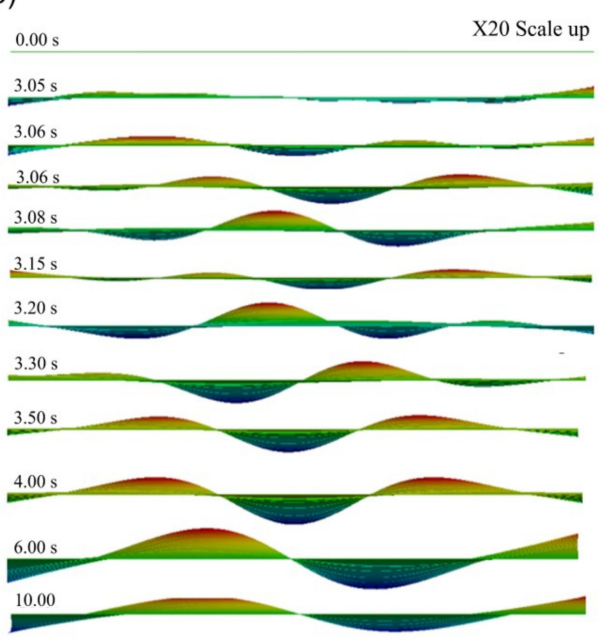

Figure 4. (a) Web moving distance over time; (b) distribution of consequent web unevenness (cross-sectional view). 


\section{Experiment}

The YSZ electrolyte layer (572349-25G, Sigma-Aldrich Inc., St. Louis, MO, USA) was coated by an industrial-scale R2R slot-die coating machine, as shown in Figure 5. The YSZ satisfied the requirements of an electrolyte layer of SOFCs and solid oxide electrolyzer cells (SOECs) due to its advantages of high ion conductivity and chemical stability [22-25].

(a)
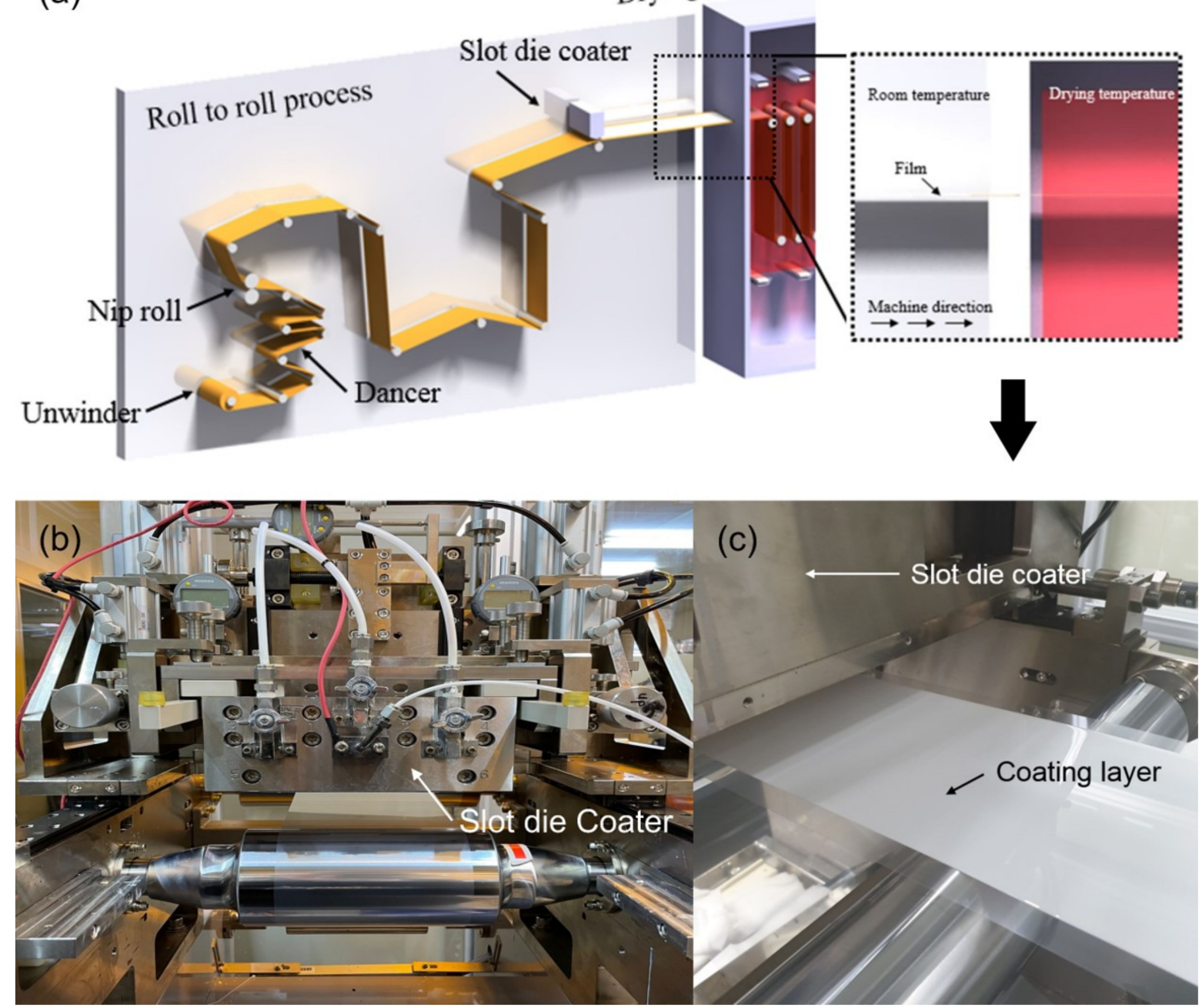

Figure 5. (a) R2R systems, (b) slot-die coater, and (c) yttria-stabilized zirconia (YSZ) layer after coating process.

\subsection{Mechanical Properties of YSZ Coating Layer}

Figure 5 a shows the schematics of the R2R slot-die coating process, and Figure 5b,c show the enlarged image of the section near the inlet of the dryer. Table 4 lists the YSZ properties, and coating and drying conditions. The coated YSZ layer was separated from the PET film (CD-901, KORON Inc., Daegu, Korea). The mechanical properties of the YSZ layer were measured by a tensile tester (Universal Testing System 3345, INSTRON Inc., Norwood, MA, USA) according to ASTM D882. 
Table 4. YSZ ink properties and processing condition of slot-die coating.

\begin{tabular}{ccc}
\hline & Properties & Value \\
\hline \multirow{2}{*}{ YSZ Ink } & Contact angle $\left({ }^{\circ}\right)$ & 61.91 \\
& Viscosity $(\mathrm{cP})$ & 30 \\
& Solid contents $(\%)$ & 35.91 \\
\hline \multirow{2}{*}{ Substrate } & Thickness $(\mathrm{mm})$ & 0.1 \\
& Width $(\mathrm{mm})$ & 150 \\
& Elastic modulus $(\mathrm{GPa})$ & 5.5 \\
& Poisson's ratio & 0.37 \\
\hline \multirow{2}{*}{ Process } & Operating tension $(\mathrm{kgf})$ & 1 \\
& Flow rate $(\mathrm{ml} / \mathrm{min})$ & 20 \\
& Web speed $(\mathrm{mm} / \mathrm{min})$ & 1000 \\
& Coating gap $(\mathrm{mm})$ & 0.35 \\
& Drying temperature $\left({ }^{\circ} \mathrm{C}\right)$ & 30 \\
\hline
\end{tabular}

Figure $6 \mathrm{a}, \mathrm{b}$ present the behavior of the YSZ layer according to tensile strain and its stress-strain curve (s-s curve), respectively. The s-s curve was plotted three times, as shown in Figure $6 \mathrm{~b}$. Average tensile stress and strain were $4.84 \mathrm{MPa}$ and 0.329 , respectively. There were few plastic-deformation regions in the s-s curves, which suggested that the YSZ layer was very brittle. Our previous study showed that tensile strain decreased with increasing drying temperature $\left(0.0088\right.$ at $50{ }^{\circ} \mathrm{C}$ and 0.0078 at $\left.70{ }^{\circ} \mathrm{C}\right)[7]$.

(a)

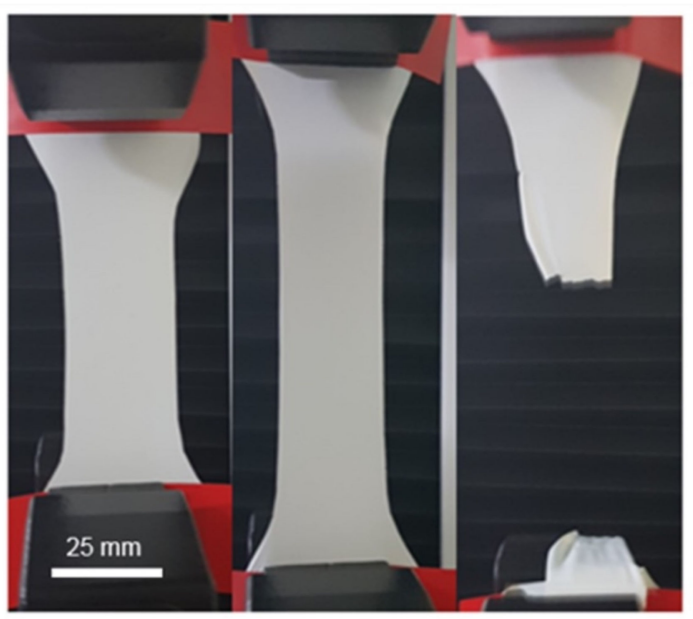

(b)

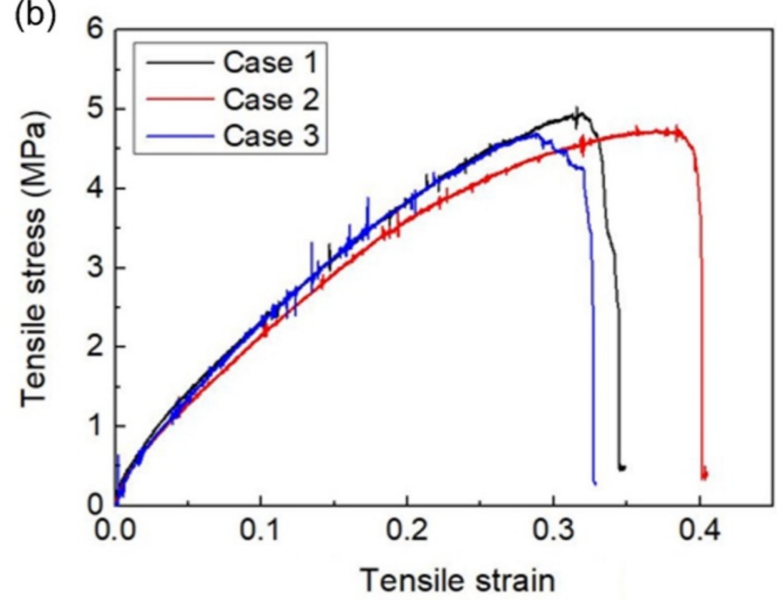

Figure 6. (a) YSZ coating layer during tensile test; (b) stress-strain curve.

\subsection{Effects of Web Unevenness on YSZ Layer Crack}

The YSZ electrolyte layers were fabricated at the four drying-temperature levels of 30, 60, 90, and $120{ }^{\circ} \mathrm{C}$ using the R2R slot-die coating process to analyze the effects of web unevenness on the crack developed in the YSZ layer. Table 5 presents the coating conditions according to drying conditions. Figure 7a,b present the dried YSZ layers coated at drying-temperature levels of 30 and $90{ }^{\circ} \mathrm{C}$, respectively. Few coating defects were obtained in the YSZ layer at $30{ }^{\circ} \mathrm{C}$; defects in the $\mathrm{x}$ direction were generated in the YSZ layer only at $90^{\circ} \mathrm{C}$. Figure 8 indicates the surface of the YSZ dried at (a-c) 30, (d-f) 60, (g-i) 90, and (j-1) $120^{\circ} \mathrm{C}$, measured by a microscope (LV100ND, Nikon, Tokyo, Japan), a scanning electron microscope (FE-SEM, S-4800, Hitachi Inc., Tokyo, Japan), and an interferometer (NS-E1000, NanoSystem Co. Ltd., Daejeon, Korea). Figure 8a,d,g,j, show more coating defects generated at higher drying-temperature levels. In particular, defect width also rose with the increase in drying temperature. The web unevenness generated in the dryer spread to the slot-die coating section, and the YSZ ink coated on the peak of web unevenness flowed down to the valley as the ink was deposited on the uneven web in the transverse direction, which generated the coating 
defect. Moreover, the dried layer where the coating defect had occurred cracked by bending due to the change in web unevenness during its movement in the dryer. The amplitude and width of the web unevenness below the lip of the slot-die coater were larger at the higher drying temperature, as shown in the simulation results in Figure 4, and that generated wider coating defects.

Table 5. Operating condition of R2R slot-die coating process.

\begin{tabular}{ccccc}
\hline Conditions & Case 1 & Case 2 & Case 3 & Case 4 \\
\hline Film width $(\mathrm{mm})$ & 150 & 150 & 0.1 & 150 \\
Film thickness $(\mathrm{mm})$ & 0.1 & 0.1 & 30 & 0.1 \\
YSZ viscosity $(\mathrm{cP})$ & 30 & 0.35 & 0.35 & 30 \\
Coating gap $(\mathrm{mm})$ & 0.35 & 1000 & 1000 & 0.35 \\
Web speed $(\mathrm{mm} / \mathrm{min})$ & 1000 & 1 & 1 & 1000 \\
Tension $(\mathrm{kgf})$ & 20 & 20 & 90 & 20 \\
Flow rate $(\mathrm{ml} / \mathrm{min})$ & 30 & 5 & 5 & 120 \\
Drying temperature $\left({ }^{\circ} \mathrm{C}\right)$ & 5 & & 5 \\
Drying time $(\mathrm{min})$ & & & 5 \\
\hline
\end{tabular}
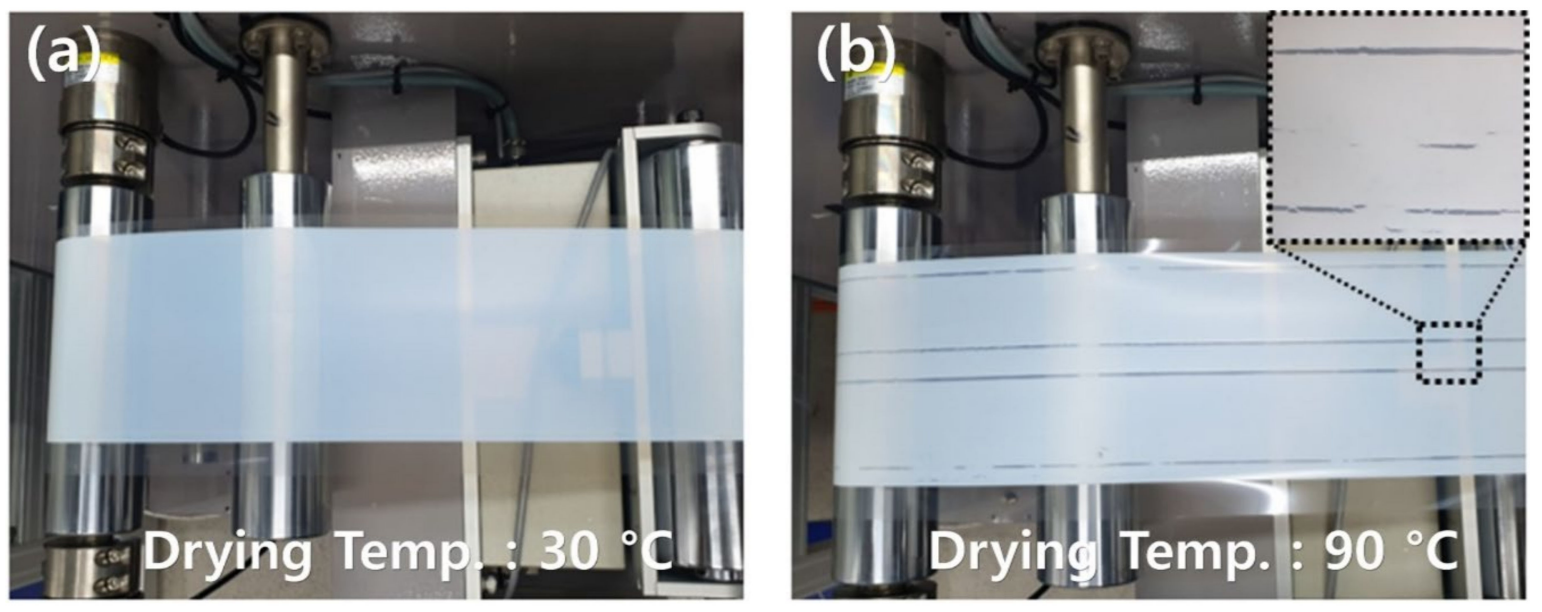

Figure 7. YSZ coating layer dried at (a) $30{ }^{\circ} \mathrm{C}$ and (b) $60{ }^{\circ} \mathrm{C}$ in $\mathrm{R} 2 \mathrm{R}$ process. 

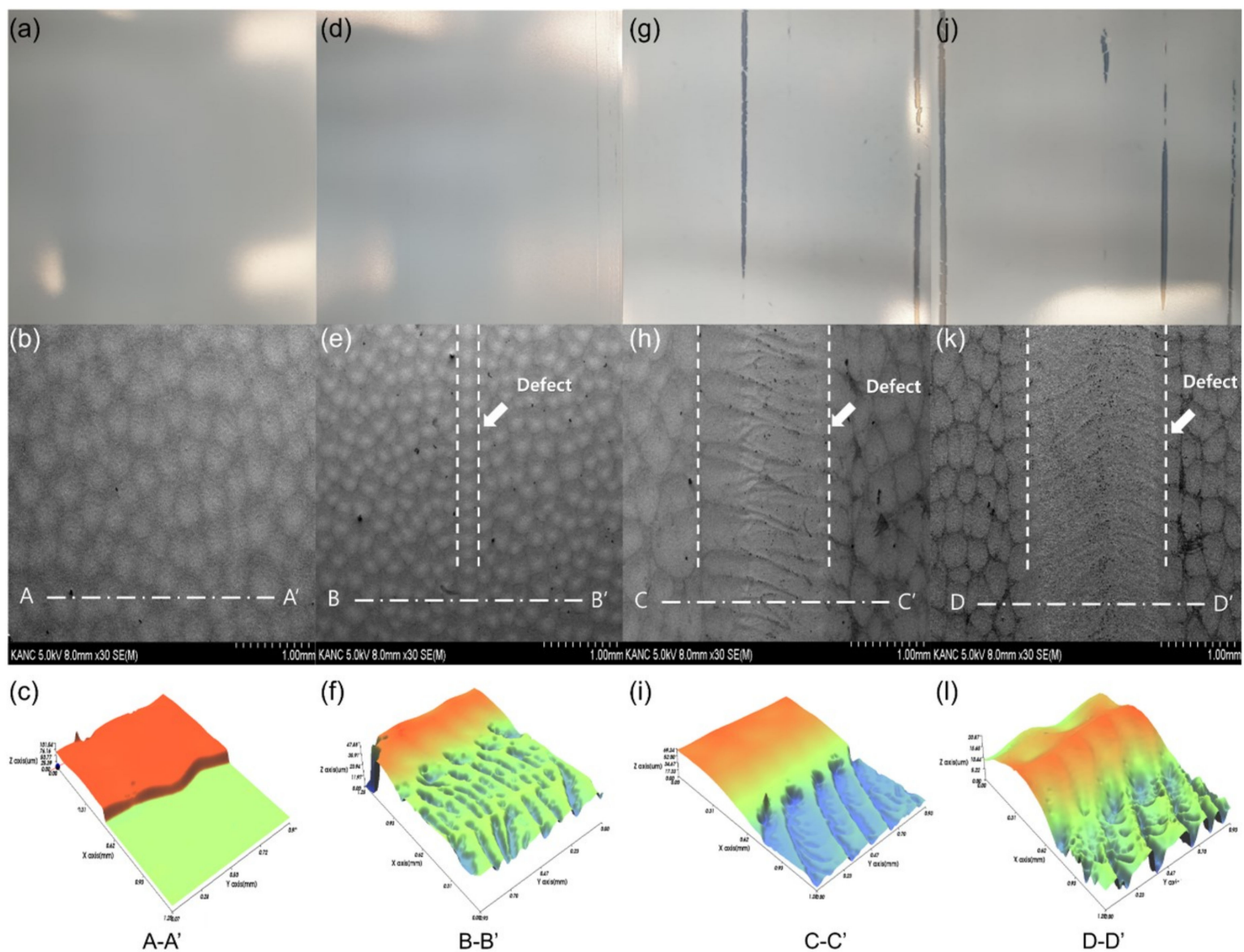

Figure 8. Surface and SEM interferometer image of YSZ coating layer dried at $(\mathbf{a}-\mathbf{c}) 30^{\circ} \mathrm{C},(\mathbf{d}-\mathbf{f}) 60^{\circ} \mathrm{C}$, $(\mathbf{g}-\mathbf{i}) 90^{\circ} \mathrm{C}$, and $(\mathbf{j}-\mathbf{1}) 120^{\circ} \mathrm{C}$.

The effects of the coating defects on SOFC performance were analyzed. SOFCs were fabricated using YSZ layers prepared at the different drying-temperature levels shown in Figure 8. Open-circuit voltage $(\mathrm{OCV})$, which directly affects the internal resistance and performance of SOFCs, was measured. Equation (2) presents the mathematical model of OCV obtained using the Nernst equation [26].

$$
E_{T}=E_{0}+\frac{R T}{2 F} \ln \left(P_{H_{2}}\right)-\frac{R T}{2 F} \ln \left(P_{H_{2} O}\right)+\frac{R T}{2 F} \ln \left(P_{O_{2}}{ }^{\frac{1}{2}}\right)
$$

where $E_{T}$ represents OCV; $R$ is the universal gas constant $\left(8.314 \mathrm{JK}^{-1} \mathrm{~mol}^{-1}\right) ; T$ and $F$ are the temperature and Faraday constant $\left(96,484 \mathrm{Cmol}^{-1}\right)$, respectively; and $P_{\mathrm{H} 2}, P_{\mathrm{H} 2 \mathrm{O}}$, and $P_{\mathrm{O} 2}$ are the partial pressures of $\mathrm{H}_{2}, \mathrm{H}_{2} \mathrm{O}$, and $\mathrm{O}_{2}$ at $1 \mathrm{~atm}$, respectively.

Figure 9 indicates the OCV measurement of SOFCs fabricated using the YSZ layer at 30, 60, 90, and $120^{\circ} \mathrm{C}$ drying temperature. OCV using the YSZ layer fabricated at 60,90 , and $120^{\circ} \mathrm{C}$ could clearly not be measured due to the coating defects. This means that the coating defects due to web unevenness could damage the SOFCs and decrease their yield in the R2R process. These results suggested that the effects of web unevenness on the coating defect due to convection and conduction heat from the dryer should be considered in fabricating the brittle electrolyte with the R2R process. For instance, the distance between slot-die coater and the inlet of the dryer can be determined by considering the minimum permissible distance at which web unevenness is not generated by considering web unevenness according to the distance between the position of the slot-die coater and dryer inlet at the drying temperature set by the user. 


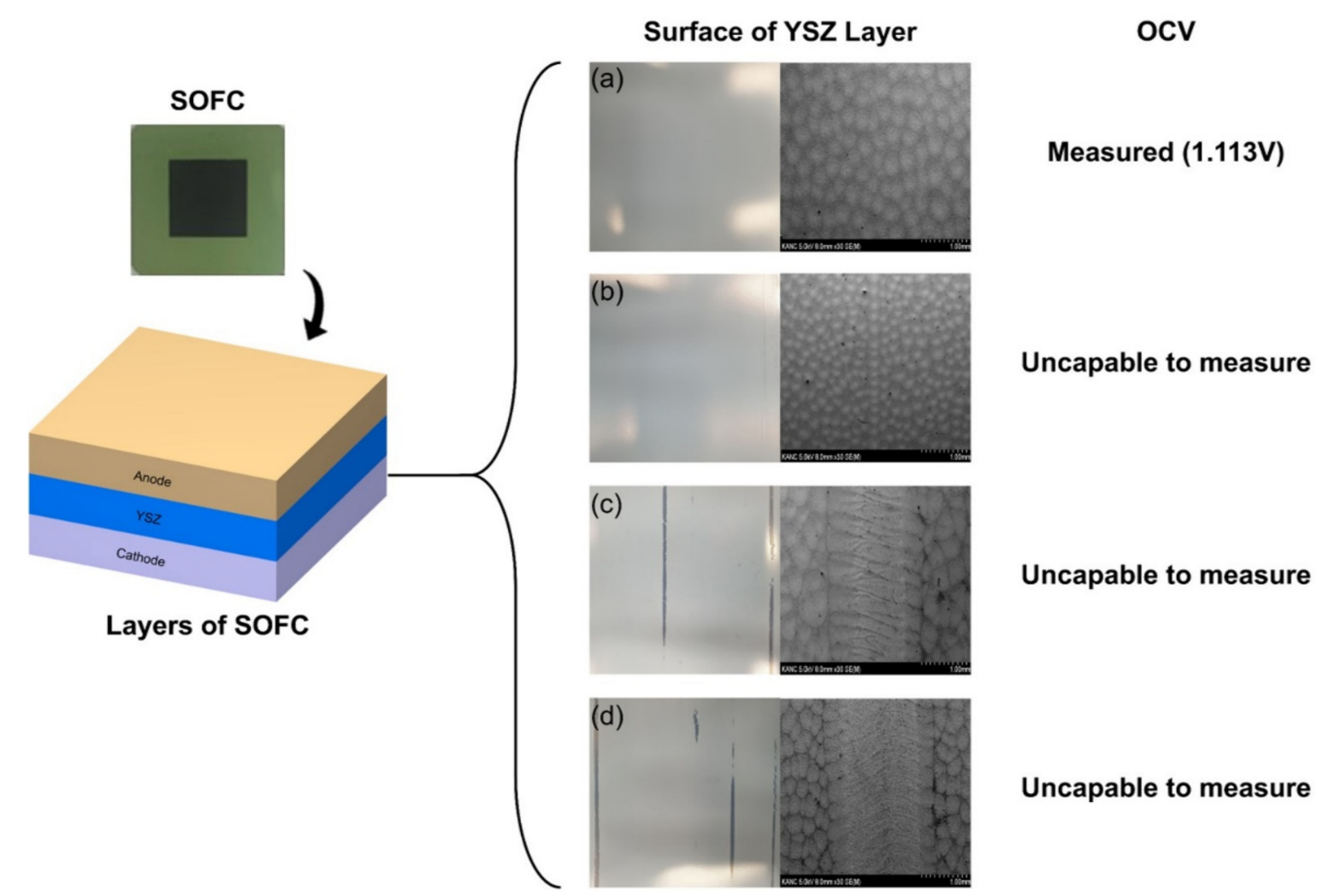

Figure 9. Open-circuit voltage (OCV) of solid oxide fuel cell (SOFC) fabricated at (a) $30{ }^{\circ} \mathrm{C},(\mathbf{b}) 60^{\circ} \mathrm{C}$, (c) $90^{\circ} \mathrm{C}$, and (d) $120^{\circ} \mathrm{C}$.

\section{Conclusions}

In this study, we analyzed the effects of thermally deformed web unevenness on the coating quality of a brittle electrolyte layer. First, the effects of conduction and convection heat from the dryer on the deformation of the tensioned web were analyzed according to drying temperature using FEA. Web unevenness could be generated by thermal deformation due to conduction and convection heat from the dryer, but the amplitudes and positions of the peaks and valleys of the uneven wave-form changed when the web moved in the dryer. The amplitude of web unevenness rose with increasing drying temperature, and web unevenness in the dryer eventually spread to the coating section. The YSZ layers were coated according to drying temperature to clearly show the effect of web unevenness on the coating defects. Results indicated that web unevenness at the coating section could generate a coating defect in the $x$ direction, which could damage the SOFC. This study suggested that coating defects generated by web unevenness because of convection and conduction heat from the dryer should be considered in the fabrication of brittle electrolytes using the R2R process. Results of this study could be useful when designing the R2R process for the mass production of large-area SOFCs.

Author Contributions: Conceptualization, M.J. and C.L.; data curation, S.K.; formal analysis, M.J., G.C., T.-M.L., and S.K.; original-draft preparation, M.J. and C.L.; supervision, J.L. and C.L.; project administration, C.L.; writing-review and editing, J.L. and C.L.; funding acquisition, C.L. All authors read and agreed to the published version of the manuscript.

Funding: This work was supported by a National Research Foundation of Korea (NRF) grant funded by the Korea government (MIST; nos. 2020R1A2C1012428 and 2020R1A5A1019649).

Conflicts of Interest: The authors declare that they have no known competing financial interests or personal relationships that could have influenced the work reported in this paper. 


\section{References}

1. Larsen-Olsen, T.T.; Andersen, T.R.; Andreasen, B.; Böttiger, A.P.L.; Bundgaard, E.; Norrman, K.; Andreasen, J.W.; Jørgensen, M.; Krebs, F.C. Roll-to-roll processed polymer tandem solar cells partially processed from water. Sol. Energy Mater. Sol. Cells 2012, 97, 43-49. [CrossRef]

2. Lee, J.; Byeon, J.; Lee, C. Theories and Control Technologies for Web Handling in the Roll-to-Roll Manufacturing Process. Int. J. Precis. Eng. Manuf. Green Technol. 2020, 7, 525-544. [CrossRef]

3. Ma, L.; Chen, J.; Tang, W.; Yin, Z. Transverse vibration and instability of axially travelling web subjected to non-homogeneous tension. Int. J. Mech. Sci. 2017, 133, 752-758. [CrossRef]

4. Lee, J.; Kim, S.; Lee, C. Taper tension profile in roll-to-roll rewinder: Improving adhesive force of pressure-sensitive adhesive film. Int. J. Precis. Eng. Manuf. Green Technol. 2019, 6, 853-860. [CrossRef]

5. Kang, H.; Lee, C. Optimal design of pneumatic flotation for roll-to-roll conveyance in the production of printed circuits. Appl. Sci. 2020, 10, 5440. [CrossRef]

6. Lee, J.; Byeon, J.; Lee, C. Fabrication of thickness-controllable double layer electrolyte using roll-to-roll additive manufacturing system. Int. J. Precis. Eng. Manuf. Green Technol. 2020, 7, 635-642. [CrossRef]

7. Lee, J.; Kim, S.; Lee, C. Surface drying for brittle material coating without crack defects in large-area roll-to-roll coating system. Int. J. Precis. Eng. Manuf. Green Technol. 2019, 6, 723-730. [CrossRef]

8. Xia, Z.C.; Hutchinson, J.W. Crack patterns in thin flms. J. Mech. Phys. Solids 2020, 48, 1107-1131. [CrossRef]

9. Ebler, N.A.; Arnason, R.; Michaelis, G.; D'Sa, N. Tension control: Dancer rolls or load cells. IEEE Trans. Ind. Appl. 1993, 29, 727-739. [CrossRef]

10. Park, J.; Kim, D.; Lee, C. Contact angle control of sessile drops on a tensioned web. Appl. Surf. Sci. 2018, 437, 329-335. [CrossRef]

11. Mollamahmutoglu, C.; Good, J.K. Modeling the influence of web thickness and length imperfections resulting from manufacturing processes on wound roll stresses. CIRP J. Manuf. Sci. Technol. 2015, 8, 22-33. [CrossRef]

12. Chen, Z.; Zheng, Y.; Zhou, M.; Wong, D.S.H.; Chen, L.; Deng, Z. Model-based feedforward register control of roll-to-roll web printing systems. Control. Eng. Pract. 2016, 51, 58-68. [CrossRef]

13. Sakamoto, T.; Fujino, Y. Modelling and analysis of a web tension control system. Proc. IEEE Int. Symp. 1995, $1,358-362$.

14. Lynch, A.F.; Bortoff, S.A.; Röbenack, K. Nonlinear tension observers for web machines. Automatica 2004, 40, 1517-1524. [CrossRef]

15. Shin, K.H.; Kwon, S.O. The effect of tension on the lateral dynamics and control of a moving web. IEEE Trans. Ind. Appl. 2007, 43, 403-411. [CrossRef]

16. Lee, C.; Kang, H.; Kim, C.; Shin, K. A novel method to guarantee the specified thickness and surface roughness of the roll-to-roll printed patterns using the tension of a moving substrate. J. Microelectromech. Syst. 2010, 19, 1243-1253. [CrossRef]

17. Lee, J.; Shin, K.; Lee, C. Analysis of dynamic thermal characteristic of register of roll-to-roll multi-layer printing systems. Robot. Comput. Integr. Manuf. 2015, 35, 77-83. [CrossRef]

18. Lu, Y.; Pagilla, P.R. Modeling of temperature distribution in a moving web transported over a heat transfer roller. In Proceedings of the Dynamic Systems and Control Conference, Fort Lauderdale, FL, USA, 17-19 October 2012.

19. Park, J.; Kim, S.; Lee, C. An analysis of pinned edge layer of slot-die coated film in roll-to-roll green manufacturing system. Int. J. Precis. Eng. Manuf. Green Technol. 2018, 5, 247-254. [CrossRef]

20. Lee, J.; Kim, S.; Lee, C. Large area electrolyte coating through surface and interface engineering in roll-to-roll slot-die coating process. J. Ind. Eng. Chem. 2019, 76, 443-449. [CrossRef]

21. Kang, Y.; Jeon, Y.; Ji, H.; Kwon, S.; Kim, G.E.; Lee, M.G. Optimizing roller design to improve web strain uniformity in roll-to-roll process. Appl. Sci. 2020, 10, 7564. [CrossRef]

22. Gao, H.; Liu, J.; Chen, H.; Li, S.; He, T.; Ji, Y.; Zhang, J. The effect of Fe doping on the properties of SOFC electrolyte YSZ. Solid State Ion. 2008, 179, 1620-1624. [CrossRef]

23. Saebea, D.; Authayanun, S.; Patcharavorachot, Y.; Chatrattanawet, N.; Arpornwichanop, A. Electrochemical performance assessment of low-temperature solid oxide fuel cell with YSZ-based and SDC-based electrolytes. Int. J. Hydrog. Energy 2018, 43, 921-931. [CrossRef]

24. Spiridigliozzi, L.; Di Bartolomeo, E.; Dell'Agli, G.; Zurlo, F. GDC-Based infiltrated electrodes for solid oxide electrolyzer cells (SOECs). Appl. Sci. 2020, 10, 3882. [CrossRef] 
25. Irshad, M.; Siraj, K.; Raza, R.; Ali, A.; Tiwari, P.; Zhu, B.; Rafique, A.; Ali, A.; Ullah, M.K.; Usman, A. A brief description of high temperature solid oxide fuel cell's operation, materials, design, fabrication technologies and performance. Appl. Sci. 2016, 6, 75. [CrossRef]

26. Chiodelli, G.; Malavasi, L. Electrochemical open circuit voltage (OCV) characterization of SOFC materials. Ionics 2013, 19, 1135-1144. [CrossRef]

Publisher's Note: MDPI stays neutral with regard to jurisdictional claims in published maps and institutional affiliations.

(C) 2020 by the authors. Licensee MDPI, Basel, Switzerland. This article is an open access article distributed under the terms and conditions of the Creative Commons Attribution (CC BY) license (http://creativecommons.org/licenses/by/4.0/). 